\title{
EFEKTIVITAS EKSTRAK DAUN JERUK PURUT (Citrus hystrix) SEBAGAI INSEKTISIDA ALAMI TERHADAP KECOAK AMERIKA (Periplaneta americana) DENGAN METODE SEMPROT
}

\author{
Hanina, Sarah Madeleyne Baringbing \\ Fakultas Kedokteran dan IImu Kesehatan Universitas Jambi \\ hanina_fkik@unja.ac.id
}

\begin{abstract}
Cockroach control can be done in various ways one of which is spraying insecticide. Natural insecticides are less dangerous than conventional insecticides. This study aimed to determined the effectiveness of kaffir lime leaf extract (Citrus hystrix) as a natural insecticide against cockroach americana (Periplaneta americana) with spray method.

This research was an experimental study with a post-test only control group designed design. The sample in this study was 60 cockroaches, the sample was divided into 6 groups: negative control (aquades), positive control (transflutrin 0.06\%) and and 4 test groups with concentrations of kaffir lime leaf extract (20\%, 40\%, $60 \%$, and $80 \%$ ) each group consisted of 10 cockroaches. Phytochemical tests were carried out to determine the content of secondary metabolites in extracts of kaffir lime leaves.

Positive phytochemical test results containing flavonoids, alkaloids and essential oils. Based on probit analysis, it is known that the LC50 value $=58.5 \%$; LC95 $=85.1 \%$. The time of death of LT50 is fastest at a concentration of $60 \%$ (3,036 hours) and LT95 is the fastest at a concentration of $80 \%$ (5,960 hours). Anova test analysis results showed that the positive control group had no significant difference with kaffir lime leaf extract concentration of $80 \%$

Kaffir lime leaf extract has an insecticide effect, the higher the concentration of kaffir lime leaf extract, the more number of dead cockroaches and the longer the observation time, the number of cockroaches death will also increase.
\end{abstract}

Keywords: American cockroach, kaffir lime leaf extract, cockroach death

\begin{abstract}
Abstrak
Pengendalian kecoa dapat dilakukan dengan berbagai cara salah satunya penyemprotan insektisida. Insektisida alami kurang berbahaya dibanding insektisida konvensional. Penelitian ini bertujuan untuk mengetahui efektifitas ekstrak daun jeruk purut (Citrus hystrix) sebagai insektisida alami terhadap kecoak americana (Periplaneta americana) dengan metode semprot.

Jenis penelitian ini adalah penelitian eksperimental dengan rancangan post-test only control group designed. Sampel dalam penelitian ini adalah 60 ekor kecoak, sampel dibagi menjadi 6 kelompok yaitu kontrol negatif (aquades), kontrol positif (transflutrin 0,06\%) dan dan 4 kelompok uji dengan konsentrasi ekstrak daun jeruk purut (20\%, 40\%, 60\%, dan 80\%) masing-masing kelompok terdiri dari 10 ekor kecoak. Uji fitokimia dilakukan untuk mengetahui kandungan senyawa metabolit sekunder pada ekstrak daun jeruk purut.

Hasil uji fitokimia positif mengandung flavonoid, alkaloid dan minyak atsiri. Berdasarkan analisis probit, diketahui nilai LC50 = 58,5\%; LC95 = 85,1\%. Waktu kematian LT50 paling cepat pada konsentrasi $60 \%$
\end{abstract}


(3,036 jam) dan LT95 paling cepat pada konsentrasi 80\% (5,960 jam). Hasil analisis uji anova menunjukkan bahwa kelompok kontrol positif tidak terdapat perbedaan yang signifikan dengan ekstrak daun jeruk purut konsentrasi $80 \%$

Ekstrak daun jeruk purut memiliki efek insektisida, semakin tinggi konsentrasi ekstrak daun jeruk purut maka jumlah kecoak yang mati semakin banyak dan semakin lama waktu pengamatan, maka jumlah kecoak yang mati juga akan semakin banyak.

Kata kunci : kecoak amerika, ekstrak daun jeruk purut, kematian kecoak

\section{Pendahuluan}

Kecoak salah satu hama pemukiman yang berperan sebagai vektor penyakit. Penularan penyakit pada kecoak secara mekanis yaitu mengkontaminasi bahanbahan makanan dan mengeluarkan bau yang tidak sedap. ${ }^{1}$

Beberapa penyakit yang ditimbulkan akibat mikroorganisme yang dibawa oleh kecoak yaitu Vibrio cholerae dan Salmonella typhosa, Enterovirus, virus polio, parasit usus misalnya Entamoeba histolytica dan Giardia lamblia, cacing usus misalnya Ascaris lumbricoides dan Trichuris trichiura dan jamur Aspergillus. ${ }^{2}$

Periplaneta americana adalah lipas berukuran besar, sekitar $3,8 \mathrm{~cm}$, berwarna coklat kemerahan. ${ }^{1}$ Pengendalian kecoak di lingkungan permukiman dapat dilakukan dengan berbagai cara seperti sanitasi lingkungan rumah, penggunaan perangkap berperekat, penyemprotan, dan pengasapan. Orang lebih banyak melakukan aplikasi insektisida seperti penyemprotan dan pengasapan ke tempattempat yang diduga menjadi tempat hidup kecoak. Insektisida itu sendiri dapat berupa alami maupun konvensional (buatan). ${ }^{1}$

Penggunaan insektisida alami mempunyai beberapa jenis salah satunya ialah botani (mengekstraksi senyawa dari tanaman untuk digunakan sebagai insektisida botani (tumbuhan). ${ }^{3}$ Senyawa tumbuhan yang diduga berfungsi sebagai insektisida diantaranya golongan sianida, saponin, tannin, flavonoid, alkalioid, steroid, dan minyak atsiri. Daun jeruk purut (Citrus hystrix) mengandung tanin, saponin, triterpenoid, dan minyak atsiri. ${ }^{4}$ Aplikasi insektisida dapat dibagi dalam empat kelompok. sehubungan dengan jenis serangga dan perilakunya yaitu space spray untuk serangga terbang, surface spray untuk serangga merayap, fumigasi, dan pengumpanan (baiting). Untuk kecoak sendiri termasuk serangga merayap sehingga jenis aplikasi yang tepat ialah surface spray. Surface spray adalah perlakuan insektisida baik yang berbentuk cair maupun bubuk pada suatu permukaan. ${ }^{5}$

Penelitian ini bertujuan untuk mengetahui efektifitas ekstrak daun jeruk purut (Citrus hystrix) sebagai insektisida alami terhadap kecoak americana (Periplaneta americana) dengan metode semprot.

\section{Metode}

Penelitian ini dilaksanakan di laboratorium Biomedik Fakultas Kedokteran dan IImu Kesehatan dan Laboratorium 
Fakultas Teknologi Pertanian Universitas Jambi pada Juni-Oktober 2019. Penelitian menggunakan metode eksperimental dengan empat tingkatan konsentrasi ekstrak daun jeruk purut $20 \%, 40 \%, 60 \%$, dan $80 \%$. Daun jeruk purut yang diperoleh kemudian dikeringkan dengan oven pada suhu $40^{\circ} \mathrm{C}$. Lalu daun dihaluskan dengan cara blender sehingga diperoleh serbuk kemudian direndam menggunakan alkohol 96\% selama 2x24 jam sebanyak 5:1. Hasil rendaman kemudian disaring dengan menggunaan kertas saring untuk memisahkan air dengan ampasnya. Setelah hasil maserat didapatkan sebanyak 8 liter kemudian diuapkan menggunakan rotary evaporator untuk didapatkan hasil ekstrak murni daun jeruk purut. Untuk mendapatkan konsentrasi yang diinginkan, ekstrak daun jeruk purut diencerkan dengan aquades ditambah tween 20 sebagai pengemulsi minyak atsiri jeruk purut sebanyak $60-80$ tetes menjadi konsentrasi $20 \%, 40 \%, 60 \%$ dan $80 \%$. Pengujian ekstrak daun jeruk purut dilakukan dengan cara menyemprotkan ekstrak ke kecoak amerika dewasa sebanyak tiga kali penyemprotan (3ml) pada daerah punggung kecoak, untuk masing-masing konsentrasi. Setelah penyemprotan, dilakukan pengamatan lama waktu yang dibutuhkan hingga kecoak mati. Penelitian ini juga melakukan uji fitokimia menggunakan tabung reaksi untuk melihat senyawa metabolit sekunder ekstrak daun jeruk purut.

\section{Tabel 1. Cara Uji Fitokimia ${ }^{6,7,8}$}

\begin{tabular}{|c|c|}
\hline Senyawa Aktif & Cara Kerja \\
\hline$\overline{\text { Alkaloid }}$ & $\begin{array}{l}\text { Ekstrak daun jeruk purut diambil kemudian dimasukkan kedalam tabung reaksi lalu } \\
\text { ditambah dua tetes dragendorf. Fitokimia Alkaloid memberikan warna jingga } \\
\text { setelah diberikan pereaksi dragendorf. }\end{array}$ \\
\hline Flavonoid & $\begin{array}{l}\text { Ekstrak daun jeruk purut sebanyak } \\
2 \text { mg ditambah tiga tetes } \mathrm{HCl} \text { pekat. Fitokimia Flavonoid memberikan warna merah } \\
\text { kejinggaan ketika ditambahkan serbuk } \mathrm{Mg} \text { dan } \mathrm{HCl} \text {. }\end{array}$ \\
\hline Saponin & $\begin{array}{l}\text { Ekstrak daun jeruk purut diambil lalu ditambahkan } 50 \mathrm{cc} \text { aquades panas kemudian } \\
\text { kocok dengan kuat setelah itu tuang satu tetes } \mathrm{HCl} \text { pekat. }\end{array}$ \\
\hline Steroid & $\begin{array}{l}\text { Ekstrak daun jeruk purut ditambah Lieberman burchard. Positif mengandung } \\
\text { steroid/triterpenoid jika terbentuk warna biru-ungu Namun jika yang terbentuk } \\
\text { warna-warna hijau hitam kebiruan maka positif mengandung monoterpenoin } \\
\text { dan sesquiterpenoid (minyak atsiri). }\end{array}$ \\
\hline Tanin & $\begin{array}{l}\text { Ekstrak daun jeruk purut sebanyak } 1 \text { gram ditambah } 10 \mathrm{cc} \text { aquades panas lalu } \\
\text { berikan } 5 \mathrm{ml} \mathrm{FeCl} 31 \% \text {. Fitokimia tannin terbentuk endapan putih }\end{array}$ \\
\hline
\end{tabular}




\section{Hasil dan Pembahasan}

Hasil uji fitokimia ekstrak alkohol $96 \%$ daun jeruk perut positif mengandung alkaloid, flavonoid dan monoterpenoin serta sesquiterpenoid sebagai penyusun minyak atsiri. ${ }^{8}$ Flavonoid berfungsi mengganggu respirasi dan menyebabkan penurunan fungsi oksigen menyebabkan segala gangguan saraf dan gangguan spirakel yang berakhir pada kematian pada serangga ${ }^{9}$, alkaloid menghambat sintesis protein sel $^{10}$, monoterpenoin serta sesquiterpenoid penyusun minyak atsiri yang menghalangi proses difusi masuknya oksigen kedalam tubuh.

Tabel 2. Hasil Uji Fitokimia

\begin{tabular}{lcl}
\hline \multicolumn{1}{c}{ Senyawa aktif } & Hasil & \multicolumn{1}{c}{ Indikator } \\
\hline Alkaloid & + & Terbentuk warna merah kecoklatan \\
Flavonoid & + & Terbentuk endapan merah kuning \\
Saponin & - & Terbentuk busa $>1 \mathrm{~cm}$ \\
Steroid & - & Terbentuk warna biru - ungu \\
Tannin & - & Terbentuk endapan putih \\
Monoterpenoid dan & & Terbentuk warna-warna hijau hitam kebiruan \\
sesquiterpenoid & + & \\
\hline
\end{tabular}

Rata-rata waktu kecoak mati paling cepat pada konsentrasi 80\% (55 menit 30 detik). Semakin rendah konsentrasi maka semakin lama rata-rata waktu kecoak mati. Hal ini digambarkan pada grafik 1 .

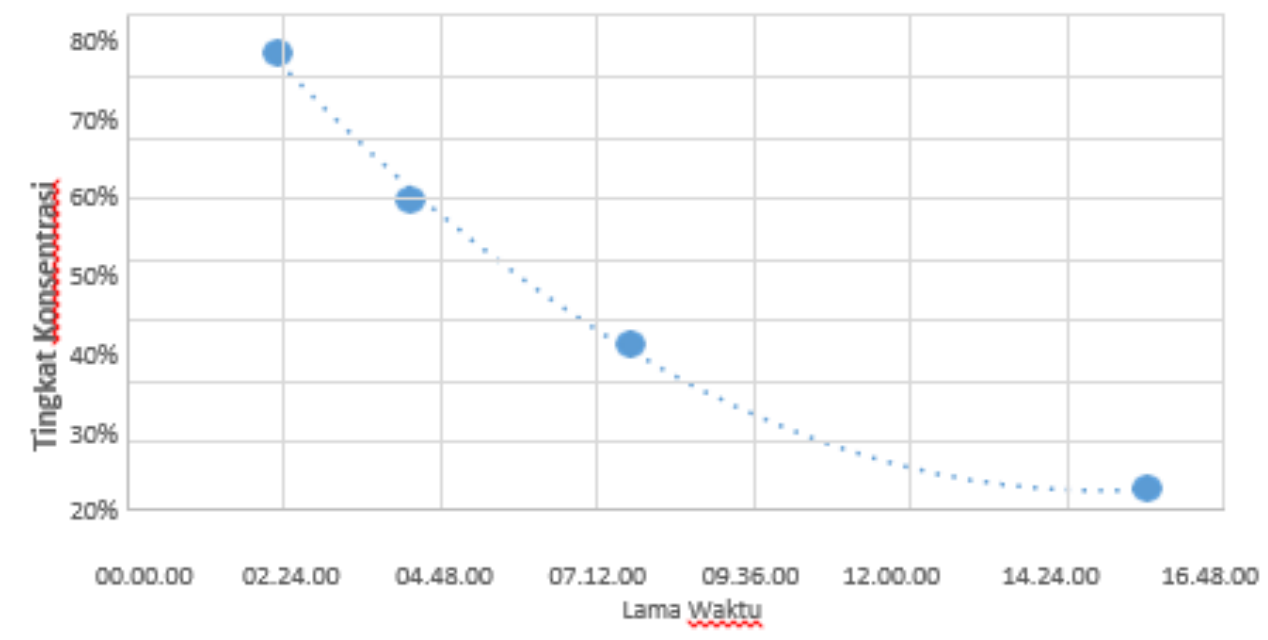

Grafik 1. Logaritma Lama Waktu Kecoak Mati Tiap Tingkat Konsentrasi Ekstrak 
Hasil analisis probit daya bunuh ekstrak daun jeruk purut terhadap Kecoak Amerika didapatkan LC50 ada pada konsentrasi 58,5\% dan LC95 Kecoak amerika ada pada konsentrasi $85,1 \%$. Sedangkan hasil dari analisis probit untuk menentukan LT50 dan LT95 tiap konsentrasi disajikan pada Tabel 3.

Tabel 3. Analisis Probit Waktu Kematian Kecoak Amerika

\begin{tabular}{ccc}
\hline Konsentrasi & LT 50 (Jam) & LT 95 (Jam) \\
\hline $20 \%$ & 16.731 & 25.548 \\
$40 \%$ & 7.146 & 12.715 \\
$60 \%$ & 3.036 & 6.663 \\
$80 \%$ & -3.148 & 5.960 \\
\hline
\end{tabular}

Tabel diatas menunjukkan bahwa pada konsentrasi $80 \%$ untuk membunuh 50\% kecoak (LT50) diperlukan waktu 3,148 jam dan LT95\% diperlukan waktu 5,96 jam. Hasil ini menunjukkan bahwa terdapat pengaruh positif penggunaan ekstrak daun jeruk purut terhadap kematian kecoak amerika. Pada hasil penelitian ekstrak akar tuba terhadap kecoak amerika didapatkan efektif LT50 pada jam ke 6,505 pada konsentrasi $3 \mathrm{~g} / 100 \mathrm{ml}$ (3\%), sedangkan LT90 pada jam ke 11,372 pada konsentrasi $9 \mathrm{~g} / 100 \mathrm{ml}$ (9\%). Oleh karena itu, penggunaan ekstrak akar tuba lebih ekonomis daripada jeruk purut dikarenakan tidak memerlukan banyak bahan aktif dalam larutan. ${ }^{11}$ LT50 ekstrak daun jeruk purut tersingkat pada kecoak adalah 3,036 jam pada konsentrasi 60\%. Sedangkan LT95 yang tersingkat adalah pada jam ke
5,960 jam tepat pada konsentrasi $80 \%$. LT50 setelah intervensi kecoak dengan konsentrasi $60 \%$ larutan ekstrak, secara berurutan tidak semakin singkat waktu kematiannya namun semakin meningkat sedikit demi sedikit. Hal ini memunculkan fenomena bahwa semakin pekat larutan maka akan menghambat aliran fluida (cairan) untuk keluar dari lubang botol sprayer sehingga waktu paparan lebih lambat. Penelitian ini diharapkan meminimalkan waktu paparan dan konsentrasi ekstrak daun jeruk purut yang digunakan terhadap kematian kecoak, karena mempertimbangkan efektivitas biaya jika akan diproduksi massal. ${ }^{11}$

Hubungan konsentrasi ekstrak daun jeruk purut terhadap kematian kecoak dianalisa dengan uji One-way anova. Hasil uji anova dapat dilihat pada Tabel 4. 
Tabel 4. Hasil Uji Analisis One-way Anova

\begin{tabular}{llc}
\hline & Standar Deviasi & Sig. \\
\hline Persentase Kecoak Mati & 4,3 & .005 \\
\hline Kelompok Perlakuan & 1,722 & .000 \\
Lama Mati Kecoak & 14,905 & \\
\hline
\end{tabular}

Berdasarkan hasil analisis di atas dapat disimpulkan terdapat perbedaan yang signifikan rata-rata lama waktu kecoak yang mati dan persentase kematian kecoak pada masing-masing kelompok perlakuan. Untuk mengetahui perlakuan mana yang berbeda dengan perlakuan yang lain, selanjutnya dilakukan uji post hoc menggunakan

\section{Kesimpulan}

Ekstrak daun jeruk purut efektif sebagai insektisida alami kecoak amerika dengan nilai LC50 sebesar 58,5\% dan LC95 sebesar $85,1 \%$. Waktu kematian kecoak (LT95) membutuhkan waktu lebih lama
Games-Howell pada taraf nyata 5\% . Pada hasil post hoc, didapatkan adanya perbedaan secara bermakna antar kelompok. Perbedaan bermakna antara konsentrasi $20 \%$, $40 \%$, $60 \%$, dan $80 \%$ dengan kontrol negatif. Perbedaan bermakna juga antara konsentrasi $20 \%$, $40 \%$, dan $60 \%$ dengan kontrol positif.

daripada membunuh kecoak sebanyak $50 \%$ (LT50) pada berbagai konsentrasi. Semakin tinggi konsentrasi ekstrak daun jeruk purut maka jumlah kecoak yang mati semakin banyak dan waktu kematian kecoak semakin cepat.

\section{DAFTAR PUSTAKA}

1. Soedarto. Buku Ajar Parasitologi Kedokteran. Sagung Seto. 2011. Hal 307.

2. Cloarec, A., Rivault, C., Fontaine, F., dan Guyader, A. Cockroaches as carriers of bacteria in multifamily dwellings. Epidemiology and Infection, 109(3), 483-490. doi:10.1017/S0950268800050470 Washington State University, Oregon State University, University of Idaho. Natural Insecticides. A Pacific Northwest Extension Publication. 2013.

3. Formulasi dan Aplikasi Insektisida [online]. Diperoleh 20 Maret 2019, dari https://wwwavisapestcontrol.blogspot.com/p/formulasi-dan-aplikasi-insektisida.html.

4. DeBach, Rosen. Biological Control by Natural Enemies. New York: Cambridge University Press. 1991; Vol 2

5. Amin, Hestiningsih, Yuliawati. Pengujian Daun Jeruk Purut (Citrus Hystrix) Sebagai Zat Penolak Alami Bagi Kecoa Jerman (Blatella Germanica) Dewasa Di Laboratorium. Jurnal Kesehatan Masyarakat $(E$ Journal). 2016; 4(1).

6. Rolliana dan Suhardjono. Uji Toksisitas Akut Ekstrak Etanol Daun Kamboja (Plumeria alba Linn) Terhadap Larva Artemia salina Leach Dengan Metode Brine Shrimp Lethality Test (BST) [Karya Tulis IImiah]. Fakultas Kedokteran Universitas Diponegoro. Semarang. 2010.

7. Baiti M, Elfrida S, Lipinwati L. Pengaruh Pemberian Ekstrak Ethanol Biji Buah Pinang (Areca Catechu L.) Terhadap Pertumbuhan Staphylococus Aureus Secara In Vitro. JMJ [Internet]. 2018Apr.4 [cited 2019Nov.20];6(1):10-9. Available from: https://online- journal.unja.ac.id/kedokteran/article/view/4817 
8. Ginting, Binawati. Antifungal Activity Of Essential Oils Some Plants In Aceh Province Against Candida Albican. Universitas Syiah Kuala. 2012; Vol 12(2):Hal 18

9. Putri, Eki Septiani. Efektivitas Daun Citrus hystrix dan Daun Syzygium Polyanthum Sebagai Zat Penolak Alami Periplaneta Americana (L.). Fakultas Kedokteran, Universitas Negeri Semarang.2017

10. Setyaningsih, Swastika. Efektivitas Ekstrak Ethanol Daun Salam (Syzygium polyanthum) Sebagai Larvasida Terhadap Larva Nyamuk Aedes aegypti. Program Studi Pendidikan Dokter FK Udayana. 2013

11. Kinansi, Handayani, Prastowo, Sudarno. Efektivitas Ekstrak Etanol Akar Tuba (Derris elliptica) terhadap Kematian Periplaneta americana dengan Metode Spraying. Balai Besar Penelitian dan Pengembangan Vektor dan Reservoir Penyakit. Jawa Tengah. 2018 